Editorial

\title{
Casaldáliga e o Araguaia: um casamento que gerou frutos eternos
}

\author{
Célia Ferreira de Sousa e Samira dos Santos Ramos
}

A Revista Alembra (RA) é um periódico de publicação online e gratuita do Instituto Federal de Educação, Ciência e Tecnologia do Estado de Mato Grosso, Campus Confresa. Promove a difusão de produção científica das grandes áreas de Letras e Humanidades contemplando Linguística, Literatura, Ciências Humanas e áreas afins, com foco às questões teóricas e críticas pertinentes aos estudos de diversidade e espacialidades, difundindo também a produção científica da região Araguaia-Xingu, e desconstruindo discursos de esquecimento e apagamento cultural.

A Revista Alembra (RA) foi idealizada e planejada no ano de 2018. Sua primeira publicação traz uma edição especial chamada Casaldáliga: o passo e marca no AraguaiaXingu, que conta com artigos que discutem a poeticidade, vida e obras de Casaldáliga, e também seu papel ativo na história de constituição educacional no território Araguaia Xingu e suas lutas em defesa dos povos tradicionais, dos oprimidos pobres, posseiros e peões.

Convidamos Aldemira Ferreira da Silva, atual Diretora de Ensino do Instituto Federal de Mato Grosso - campus Confresa, por seu engajamento na educação no Araguaia e vivência próxima ao bispo Casaldáliga, a apresentar esta edição. Silva contextualiza a luta de Pedro no espaço social, político e geográfico do Araguaia.

A autora Cleonilde Ribeiro de Souza em seu artigo Poesia e política: a voz do "eu" que se torna "nós/povo" na palavra cantada de Pedro Casaldáliga, mostra a partir da análise de cinco poemas de Casaldáliga, as relações socioculturais de países imersos em lutas e em guerras na década de 1970 e 80. Mostra uma poética de cunho social que dialoga a respeito da possibilidade de ressignificação dos lugares desumanizados.

Edson Flavio Santos, no artigo A poética das águas: um olhar líquido sobre a poesia de Pedro Casaldáliga, coloca em relevo parte da produção de Casaldáliga, a vocação e empenho para com a mensagem poética de luta pela promoção humana e comprometimento social com as causas dos menos favorecidos. 
No artigo O bispo Pedro Casaldáliga e sua opção preferencial na luta pela terra no norte Araguaia, os autores mostram as contribuições de Casaldáliga na luta pela terra na microrregião geográfica denominada Norte Araguaia.

Em A Glocalização da educação na Região do Araguaia - pela janela de Casaldáliga, os autores tecem uma compreensão e reflexão discursivamente, acerca da definição de Educação numa perspectiva libertadora na definição de Casaldáliga, institucionalizada por meio da Prelazia de São Félix do Araguaia-MT.

E em O surgimento do Programa Parceladas e sua consolidação no médio Araguaia, os autores trazem em evidência as contribuições de Casaldáliga para a consolidação da Formação inicial de professores na Região do Araguaia via UNEMAT. Afirmam ainda que Dom Pedro Casaldáliga foi e é referência na história de luta pela terra e pela educação protagonizada pelos movimentos sociais e pela Prelazia de São Felix do Araguaia na defesa de uma educação pública e de qualidade.

A Edição Especial Casaldáliga: o passo e marca no Araguaia-Xingu nos propõe a retomar os passos de Dom Pedro no Araguaia e a enxergar as marcas de sua luta nas esferas educacionais, políticas, discursivas e poéticas deixaram na região que já foi cunhada como Vale dos Esquecidos. O passo e a marca de Casaldáliga mostra que há muito do que se AlembrA.

Desejamos a todos uma boa leitura! 